\title{
Two outer membrane proteins are bovine lactoferrin-binding proteins in Mannheimia haemolytica A1
}

\author{
Luisa Samaniego-Barrón', Sarahí Luna-Castro² , Carolina Piña-Vázquez ${ }^{1}$, Francisco Suárez-Güemes ${ }^{3}$ \\ and Mireya de la Garza ${ }^{1 *}$ D
}

\begin{abstract}
Mannheimia haemolytica is a Gram negative bacterium that is part of the bovine respiratory disease, which causes important economic losses in the livestock industry. In the present work, the interaction between M. haemolytica A1 and bovine lactoferrin (BLf) was studied. This iron-chelating glycoprotein is part of the mammalian innate-immune system and is present in milk and mucosal secretions; Lf is also contained in neutrophils secondary granules, which release this glycoprotein at infection sites. It was evidenced that $M$. haemolytica was not able to use iron-charged BLf (BholoLf) as a sole iron source; nevertheless, iron-lacked BLf (BapoLf) showed a bactericidal effect against M. haemolytica with MIC of $4.88 \pm 1.88$ and $7.31 \pm 1.62 \mu \mathrm{M}$ for M. haemolytica strain F (field isolate) and M. haemolytica strain $\mathrm{R}$ (reference strain), respectively. Through overlay assays and 2-D electrophoresis, two OMP of 32.9 and $34.2 \mathrm{kDa}$ with estimated IP of 8.18 and 9.35, respectively, were observed to bind both BapoLf and BholoLf; these OMP were identified by Maldi-Tof as OmpA (heat-modifiable OMP) and a membrane protein (porin). These M. haemolytica BLf binding proteins could be interacting in vivo with both forms of BLf depending on the iron state of the bovine.
\end{abstract}

\section{Introduction}

Mannheimia haemolytica is an opportunistic Gramnegative bacterium that belongs to the Pasteurellaceae family. This bacterium is part of the bovine respiratory disease (BRD), which causes important economic losses in livestock. The influence of the environment, stressing factors, and infections by viruses and bacteria, causes BRD; these factors seem to alter the bovine upper respiratory-tract epithelium allowing $M$. haemolytica to colonize it, escape clearance and move from the nasopharynx to the lungs, leading to pneumonia [1]. Transportation of animals is the most accepted non-infectious risk factor including distance, method, and dehydration; ambient factors, like abrupt and extreme changes in weather conditions, rather than simply cold or inclement weather,

\footnotetext{
*Correspondence: mireya@cell.cinvestav.mx

${ }^{1}$ Departamento de Biología Celular, Centro de Investigación y de Estudios Avanzados del IPN (CINVESTAV-IPN), Avenida Instituto

Politécnico Nacional No. 2508, Colonia San Pedro Zacatenco, CP 07360 Ciudad de México, Mexico

Full list of author information is available at the end of the article
}

predispose cattle to $\mathrm{BRD}$. Among bovine viruses, the main are herpes-1, respiratory syncytial, viral diarrhea, and parainfluenza-3, all of them causing immunosuppression [2-4]. The bacterial pathogens that more frequently infect after the viral infection are M. haemolytica and Pasteurella multocida. Other pathogens are Histophilus somni, Mycoplasma bovis, and Trueperella pyogenes. There are twelve M. haemolytica serotypes, from which, A1 is found with more frequency in pneumonic bovines [5]. M. haemolytica infection causes a fibrinosuppurative and necrotizing inflammatory response in the lungs. M. haemolytica possesses numerous pathogenicity mechanisms that allow bacterial invasion and colonization leading to pulmonary injury. Within the reported pathogenicity, determinants are leukotoxin [6]; lipopolysaccharide (LPS) [7]; capsule [8]; outer membrane proteins (OMP) and membrane lipoproteins [9-11]; adhesins [12]; fimbriae [13]; enzymes (neuraminidase, metalloglycoproteases, and IgA and IgG proteases) [14]; and antimicrobial resistance plasmids [15-17]. $M$. haemolytica possesses specific iron uptake mechanisms 
for bovine holotransferrin (BholoTf) (TbpA and TbpB of 71 and $77 \mathrm{kDa}$, respectively, in the A1 serotype) [18]. Interestingly, $M$. haemolytica does not produce siderophores; however, receptors for siderophores have been found in its genome. M. haemolytica genes coding HmbR1 and HmbR2 proteins to capture hemoglobin and the use of this ferrous protein as an iron source have been demonstrated [19].

Lactoferrin (Lf) is an $80 \mathrm{kDa}$ cationic non-heme glycoprotein that belongs to the mammalian innate-immune system, with higher affinity for iron than transferrin (Tf); depending on the amount of iron, Lf could be iron-free (apoLf) or charged with one or two iron atoms (holoLf) [20]. Lf is found in high concentration in colostrum and milk (5-7 and $1 \mathrm{mg} / \mathrm{mL}$, respectively), and in a lower concentration in other body secretions, such as intestinal and respiratory secretions. Lf is also produced by the secondary granules of neutrophils, which release this protein at infection sites [21]. Lf is a multifunctional protein, since it displays serine protease activity, and it is also antiinflammatory, immunomodulatory, and anticarcinogenic [22]. The interaction of Lf with microorganisms leads to different outcomes depending on the Lf form; in this sense, holoLf can serve as an iron source whereas apoLf generally causes microbial death. ApoLf can be bacteriostatic, since it chelates the iron needed for pathogenic growth in fluids and mucosae. In addition, apoLf can cause death in certain pathogenic species, because Lf alters the OM permeability causing the release of LPS in Gram negative bacteria. Lf also binds to porins affecting their permeability and thus allowing the influx of toxins and antibiotics [23-26]. In addition, it has been demonstrated that the $\mathrm{N}$-terminus of $\mathrm{Lf}$ is responsible for the bactericidal effect; peptides from this $\mathrm{N}$-terminus can be obtained by cleavage with pepsin, and they have been named lactoferricins (Lfcins) [27]. Lf also inhibits bacterial aggregates and biofilm formation. Interestingly, apoLf can potentiate the bactericidal effect of antimicrobials; our group demonstrated A. pleuropneumoniae death by apoLf, and a synergistic activity of apoLf with oxytetracycline [28]. The bactericidal effect of apoLf has also been demonstrated in Aggregatibacter actinomycetemcomitans [29]; both bacterial species belong to the Pasteurellaceae family. Concerning the use of holoLf as a sole iron source, the iron uptake by receptors has been more extensively studied in the Neisseriaceae family [30]. In Neisseria meningitidis, Neisseria gonorrhoeae, Moraxella catarrhalis and Moraxella bovis, the OMP LbpA and LbpB (105 and $80-100 \mathrm{kDa}$, respectively) have been described as binding proteins to holoLf. In addition, Lbps of 105 and $106 \mathrm{kDa}$ displayed binding to human holoLf in Haemophilus influenzae, another member of the Pasteurellaceae family [31]. However, $l b p A$ and $l b p B$ genes homologous to those of the Neisseriaceae family were not found in the genomes of A. pleuropneumoniae and M. haemolytica [18]. Since $M$. haemolytica is constantly interacting with the bovine innate-immune system in respiratory mucosa, the aim of this work was to determine the type of relationship that takes place between the host Lf and $M$. haemolytica. A bactericidal effect was found for BapoLf, meanwhile holoLf was not used by the bacteria as a sole iron source. Both apoLf and holoLf were bound to two OMP of 32.9 and $34.2 \mathrm{kDa}$ with estimated IP of 8.18 and 9.35, which were identified as OmpA (heat-modifiable protein) and a membrane protein (porin), respectively.

\section{Materials and methods}

\section{Strains and growth conditions}

Two strains of $M$. haemolytica A1 were used, a field isolate from a pneumonic bovine (MhF), previously identified by conventional culture and API 20E tests, as well as indirect hemagglutination assay to establish the serotype [5]. The other strain (MhR) was kindly donated by G. H. Frank and R. E. Briggs from the National Animal Disease Center, United States Department of Agriculture. Actinobacillus pleuropneumoniae serotype 1 (strain S4074) was used as a negative control of BholoLf utilization as an iron source [28]; this strain was kindly donated by $\mathrm{M}$. Gottschalk (Groupe de Recherche sur Maladies Infectieuses de Porc, Université de Montréal, Canada). An isolate of Moraxella bovis from a bovine suffering keratoconjunctivitis (identified by API 20E test), was used as a positive control of BholoLf utilization as an iron source [32]. Mannheimia haemolytica and M. bovis strains were regularly grown in 5\% sheep blood agar for their use. A. pleuropneumoniae was regularly grown in TSA plus NAD $(15 \mu \mathrm{g} / \mathrm{mL})$.

\section{Reagents}

Bovine apoLf (BapoLf) was purchased at NutriScience Innovations LLC, USA, and contained $0.005 \%$ iron. BapoLf was saturated with iron to obtain BholoLf according to the method described by Schryvers and Morris [33]; iron in BholoLf was 91.6\%; it was quantified by an enzymatic automated method (MicroTech Laboratories, Mexico). Lactoferricin B (fragment 4-14), 2,2'-dipyridyl and bovine serum albumin (BSA) were purchased from Sigma. The protein assay for method of Bradford, was purchased from Bio-Rad, USA.

\section{Use of bovine hololactoferrin as a sole iron source by $M$. haemolytica A1}

First, several concentrations $(0.1-0.5 \mathrm{mM})$ of the ironchelating agent $2^{\prime} 2$ dipyridyl were added to BHI broth (Dibico, México), to determine an optimal iron chelation without causing bacterial death. After that, a minimal 
ferric-iron concentration was established for M. haemolytica growth by testing concentrations of 20,40, 60, 80 and $100 \mu \mathrm{M} \mathrm{FeCl}_{3}$ in the presence of $0.4 \mathrm{mM} 2,2$-dipyridyl. The optimal $2^{\prime} 2$ dipyridyl concentration for $M$. bovis and $A$. pleuropneumoniae were 0.15 and $0.5 \mathrm{mM}$, respectively. Later, to know whether $M$. haemolytica can use BholoLf as an iron source, an initial culture in BHI broth at an $\mathrm{OD}_{595}=0.02$ was subcultured in different conditions: (1) BHI broth as a positive control of growth; (2) iron-chelated broth as a negative control of growth; (3) iron-chelated broth with $80 \mu \mathrm{M} \mathrm{FeCl}_{3}$; (4) iron-chelated broth supplemented with BholoLf $(80 \mu \mathrm{M}$ iron concentration). A. pleuropneumoniae serotype 1 and $M$. bovis were used as negative and positive control of BholoLf utilization as an iron source, respectively. Samples were incubated at $37{ }^{\circ} \mathrm{C}$ with agitation (200 rpm) and the $\mathrm{OD}_{595 \mathrm{~nm}}$ was registered at $24 \mathrm{~h}$. Growth was done in three independent experiments each in triplicate. The results were expressed as the mean \pm standard deviation and the statistical significance was searched with the Student's $t$ test.

\section{Effect of bovine apolactoferrin on the growth of $M$. haemolytica}

The minimum inhibitory concentration (MIC) of BapoLf on the $M$. haemolytica A1 growth was determined employing the method of microdilution in BHI broth plus BapoLf. Bacteria ( $10^{5}$ UFC) were incubated with 0 , $3.25,6.5,9.75,13.0,16.25,19.5,22.75$ and $26 \mu \mathrm{M}$ BapoLf up to $18 \mathrm{~h}$ at $37{ }^{\circ} \mathrm{C}$ in sterilized 96 well plates, and the $\mathrm{OD}$ at $595 \mathrm{~nm}$ was recorded. All of the experiments were repeated three times in triplicate.

\section{OMP extraction and overlay}

Overlays were performed from $M$. haemolytica OMP. First, OMP were extracted according to the protocol previously described by Brennan [34]. Bacteria were harvested from $\mathrm{BHI}$ broth by centrifugation at $6000 \times g$, washed twice in $20 \mathrm{mM}$ Tris ( $\mathrm{pH} 7.2$ ), and sonicated with $0.75^{\prime \prime}$ probe $(55 \mu \mathrm{m}$, amplitude setting $9.20 \mathrm{~Hz})$ on ice for $10 \mathrm{~min}$. Sonicate was centrifuged at $6000 \times g$ for $20 \mathrm{~min}$ to remove cell detritus. The supernatant was removed with a pipette, placed into a clean tube and pelleted at $60000 \times g$ for $1 \mathrm{~h}$. The supernatant was then removed and the pellet was suspended in $1 \mathrm{~mL}$ of $20 \mathrm{mM}$ Tris $(\mathrm{pH}$ 7.2). Cytoplasmic membranes were solubilized by adding $4 \mathrm{~mL}$ of $0.5 \% \mathrm{~N}$-lauryl-sarcosine and incubated at room temperature for $30 \mathrm{~min}$. Clumps were broken up by pipetting up and down several times. The OMP were pelleted at $60000 \mathrm{~g}$ for $1 \mathrm{~h}$ and washed once in $20 \mathrm{mM}$ Tris ( $\mathrm{pH} 7.2)$, and the protein concentration was determined by the method of Bradford [35]. The OMP were separated by $12 \%$ SDS-PAGE, later the proteins were transferred to a nitrocellulose membrane, at $300 \mathrm{~mA}$ for $1 \mathrm{~h}$, and the membrane was blocked with TBS-Tween at 0.05 and $4 \%$ BSA. The membrane was washed with TBS and incubated with the following compounds coupled to horseradish peroxidase (HRP): $1 \mu \mathrm{g} / \mathrm{mL}$ of BapoLf, BholoLf, or lactoferricin B (fragment 4-14). Also, a competition binding test was made by incubating the membrane with BapoLf $100 \times$ (without HRP) and then incubating with each one of the proteins or the peptide coupled to HRP. All the membranes were revealed by chemiluminescence.

\section{Two-dimensional (2-D) SDS-PAGE}

The outer membrane proteins were cleaned using Ready Prep $^{\text {TM }}$ 2-D cleanup kit (Bio-Rad), and proteins were dissolved in Ready Prep ${ }^{\mathrm{TM}}$ 2-D starter kit Rehydration/sample buffer (Bio-Rad); this sample was used to passively rehydrate the immobilized $\mathrm{pH}$ gradient (IPG) ReadyStrips (7 and $17 \mathrm{~cm}$, linear, $\mathrm{pH}$ 3-10; Bio-Rad) during $16 \mathrm{~h}$ at $20{ }^{\circ} \mathrm{C}$. Isoelectrofocusing (IEF) of the proteins was run in a Protean IEF Cell System (Bio-Rad) in the following steps: $250 \mathrm{~V}$ for a $20 \mathrm{~min}$ linear ramp, $250 \mathrm{~V}$ for a $1 \mathrm{~h}$ rapid ramp, $500 \mathrm{~V}$ for a $1 \mathrm{~h}$ rapid ramp, $400 \mathrm{~V}$ for a $2 \mathrm{~h}$ linear ramp, and $4000 \mathrm{~V}$ with a rapid ramp up to $10000 \mathrm{~V}$-h. After reduction and alkylation in the equilibration buffer, IPG strips were subjected to separation by MW on $12 \%$ SDS-PAGE. The gel was transferred onto a nitrocellulose membrane and processed for overlay with the different proteins labeled with HRP (see above). To identify the spots corresponding to the proteins that bind BLf, the image obtained from the revealed membrane and the gel stained with Coomassie blue G-250 (Bio-safe, Bio-Rad) were merged, using image J software [36] by aligning MW markers and membrane borders. Obtaining OMP that bound BapoLf as well as overlay assays were performed in three independent experiments.

\section{Identification of the bovine apolactoferrin binding proteins}

The previously identified spots were cut from the stained Coomassie gel, and distained with ACN: $50 \mathrm{mM}$ $\mathrm{NH}_{4} \mathrm{HCO}_{3}(1: 1, \mathrm{v} / \mathrm{v})$, and protein digestion was performed for $18 \mathrm{~h}$ at $37{ }^{\circ} \mathrm{C}$ with trypsin (masses grade, Promega V528A). The peptides were extracted from the digestion ( $\mathrm{ACN}: \mathrm{H}_{2} \mathrm{O}$ :formic acid 50:45:5 v/v), and the sample volume was decreased in an Eppendorf concentrator (Eppendorf 5301) and desalted using a C18 column (ZipTipC18). The sample was placed by sixfolds on the plate using $\alpha$-cyan as a matrix, and analyzed in Maldi TOF/TOF 4800. Identification of the spots was made two times in independent samples. The MS/MS spectra data was searched in the database (NCBI-nr) and protein identification was performed using the MASCOT search algorithm (Version 1.6b9, Matrix Science) [37]. 


\section{Bioinformatics analyses}

All the similarity searches of protein sequences were analyzed by BLAST [38]. Multiple sequence alignments were conducted using the Clustal Omega software website [39], the prediction of secondary structure was performed with PSS PRED [40], and edited using ESPRIPT 3.0 [41]. Search for protein families and predicting domains was performed at InterPro database at the European Bioinformatics Institute [42]. For a discrimination of the $\beta$-barrel structure of OMP and 2-D representation, MCMBB online tools were used [43]; the predicting and discriminating $\beta$-barrel OMP were performed with Hidden Markov Models PRED-TMBB [44]. Structure prediction was made using the I-TASSER server for protein 3-D models [45]. For quality estimation for 3-D models, a QMEAN server was used [46]. Molecular docking between $M$. haemolytica OMP and Lf was executed with the ClusPro server [47], and molecular graphics were performed with the USCF Chimera package; Chimera was developed by the Resource for Biocomputing, Visualization, and Informatics at the University of California, San Francisco (supported by NIGMS P41-GM103311) [48].

\section{Results}

Bovine hololactoferrin was not used as a sole iron source by $M$. haemolytica, and bovine apolactoferrin showed a bactericidal effect against this bacterium

In iron-chelated BHI medium (Additional file 1), both strains of $M$. haemolytica required $80 \mu \mathrm{M}$ iron (from $\mathrm{FeCl}_{3}$ ) for growing, under the conditions tested in this work; however, this bacterial species was not able to grow when BholoLf was added as a sole iron source to the iron-chelated BHI broth, even with $80 \mu \mathrm{M}$ iron derived from BholoLf (Figure 1). The negative control $A$. pleuropneumoniae showed a similar negative behavior, as demonstrated in previous work [28]. M. bovis, the positive control of BholoLf utilization as an iron source, grew in the presence of this iron-charged protein. On the contrary, BapoLf inhibited the growth in vitro of both $M$. haemolytica strains; MIC obtained were $4.88 \pm 1.88$ and $7.31 \pm 1.62 \mu \mathrm{M}$ for $\mathrm{MhF}$ and $\mathrm{MhR}$, respectively.

\section{Bovine lactoferrin mainly binds to two M. haemolytica outer membrane proteins}

To determine whether $M$. haemolytica possesses BLf binding proteins, overlays were performed with extracted OMP and binding to HRP-coupled BholoLf and BapoLf was explored. A main band of $40 \mathrm{kDa}$ was observed in the two strains for both forms of Lf (Figures 2A and $B)$. To know whether this band could correspond to the same binding protein for BholoLf and BapoLf, a competition binding assay was made. As no band was visualized using BapoLf in competence with HRP-BholoLf, and vice versa, the result suggests that apo and holo forms of BLf bind to the same $M$. haemolytica OMP (Figure 2C). Next, a competition assay using HRP-BLfcin $\left(\mathrm{BLf}_{4-14}\right.$ peptide) was made and no band was visualized using BapoLf in competence with HRP-BLfcin (Figure 2D). The results together suggest that $M$. haemolytica possesses at least one OMP that binds both forms of BLf and the binding could be through the N-terminus of BLf.

As the results with both strains of $M$. haemolytica were similar in the binding to BLf, only the MhF strain OMP were used to perform 2-D electrophoresis. The OMP separated by 2-D electrophoresis were transferred to a membrane and incubated with HRP-BapoLf. Interestingly, two spots of 32.9 and $34.2 \mathrm{kDa}$ were found, with estimated IP of 8.18 and 9.35 , respectively (Figure $3 \mathrm{~B}$ ). The corresponding two spots in the 2-D gel (Figure 3A) were cut and analyzed by Maldi-tof. A search was realized using the Mascot database of the MS/MS spectra obtained from two independent experiments. For both experiments, the two spots were identified as the heat-modifiable OMP (MhHM) [UniProt: Q6XAY2; gi|45758055] and an unknown OMP (MhMP) [UniProt: S9YBF1; gi|544866807] of M. haemolytica, with 34 and 39\% coverage for the spots 1 and 2, respectively. Characteristics of the identified proteins are shown in Table 1. MhHM is encoded by the ompA gene, whereas the L278_12700 gene encodes MhMP. Both proteins have a signal peptide in the 1-19 position, and the analysis of peptides is listed in Additional files 2 and 3 . Identity with other protein sequences was searched with NCBI-BLAST; the main identities are shown in Tables 2 and 3 ; in both cases the highest percentage of identity corresponds to proteins of the Pasteurellaceae family members. Sequences of MhHM and MhMP were aligned with Clustal Omega. Several identity sites were found, the alignment and prediction of secondary structure is shown in Figure 4. The differences in the sequences demonstrate that they are two different proteins of $M$. haemolytica; nevertheless, the identity regions could be the BLf binding sites in both OMP.

\section{MhHM and MhMP domains}

Protein domains were searched in the website InterPro. MhHM belongs to the protein family OmpA [IPR002368]; proteins of this family contain two domains; one of them is the OmpA-like transmembrane domain at the $\mathrm{N}$-terminus [IPR000498] consisting of an eight stranded $\beta$-barrel and the other one is an OmpA C-like domain [IPR006665], similar to the C-terminal domain of OmpA peptidoglycan-binding domain. Concerning the other BLf binding protein, MhMP, the domain searched in website InterPro resulted in a conserved domain in Gram-negative porins [IPR023614]. 


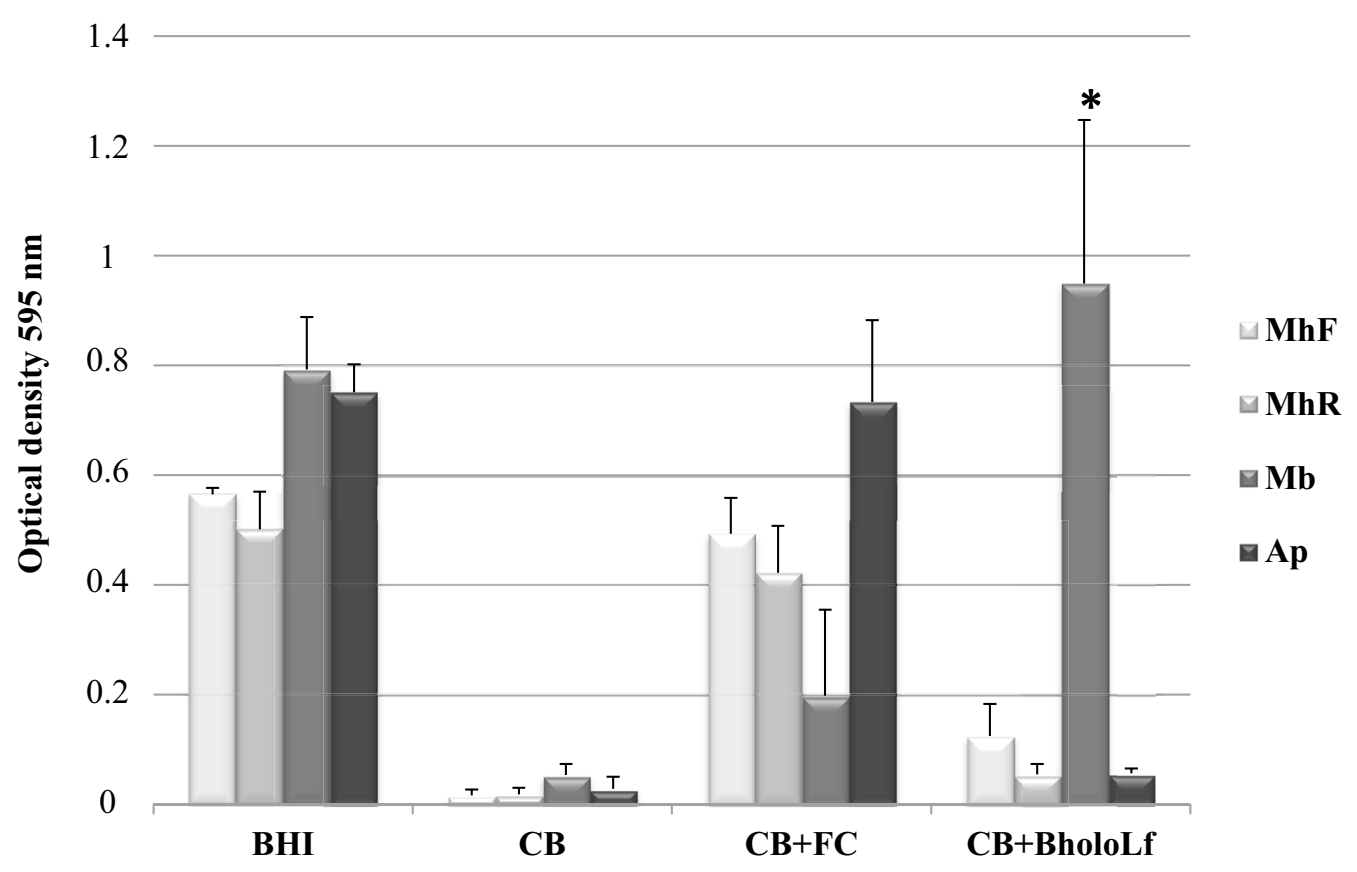

Figure 1 Evaluation of bovine holo-lactoferrin (BholoLf) as a sole iron source in Mannheimia haemolytica strains (MhF and MhR). Moraxella bovis was used as positive control and Actinobacillus pleuropneumoniae as a negative control of use of BholoLf. The bacterial growth was determined by $\mathrm{OD}_{595 \mathrm{~nm}}$, at $24 \mathrm{~h}$ of incubation at $37^{\circ} \mathrm{C}$, in agitation (200 rpm) in different conditions: $\mathrm{BHI}$, Brain heart infusion broth; $\mathrm{CB}, \mathrm{BHI}$ chelated with dipyridyl; $C B+F C$, chelated BHI plus ferric chloride $[80 \mu \mathrm{M}] ; C B+$ BholoLf, chelated BHI plus BholoLf [80 $\mu M$ of iron]. The results are shown as the mean $\pm S D,{ }^{*} p<0.05$ versus $C B$ and $C B+$ BholoLf.

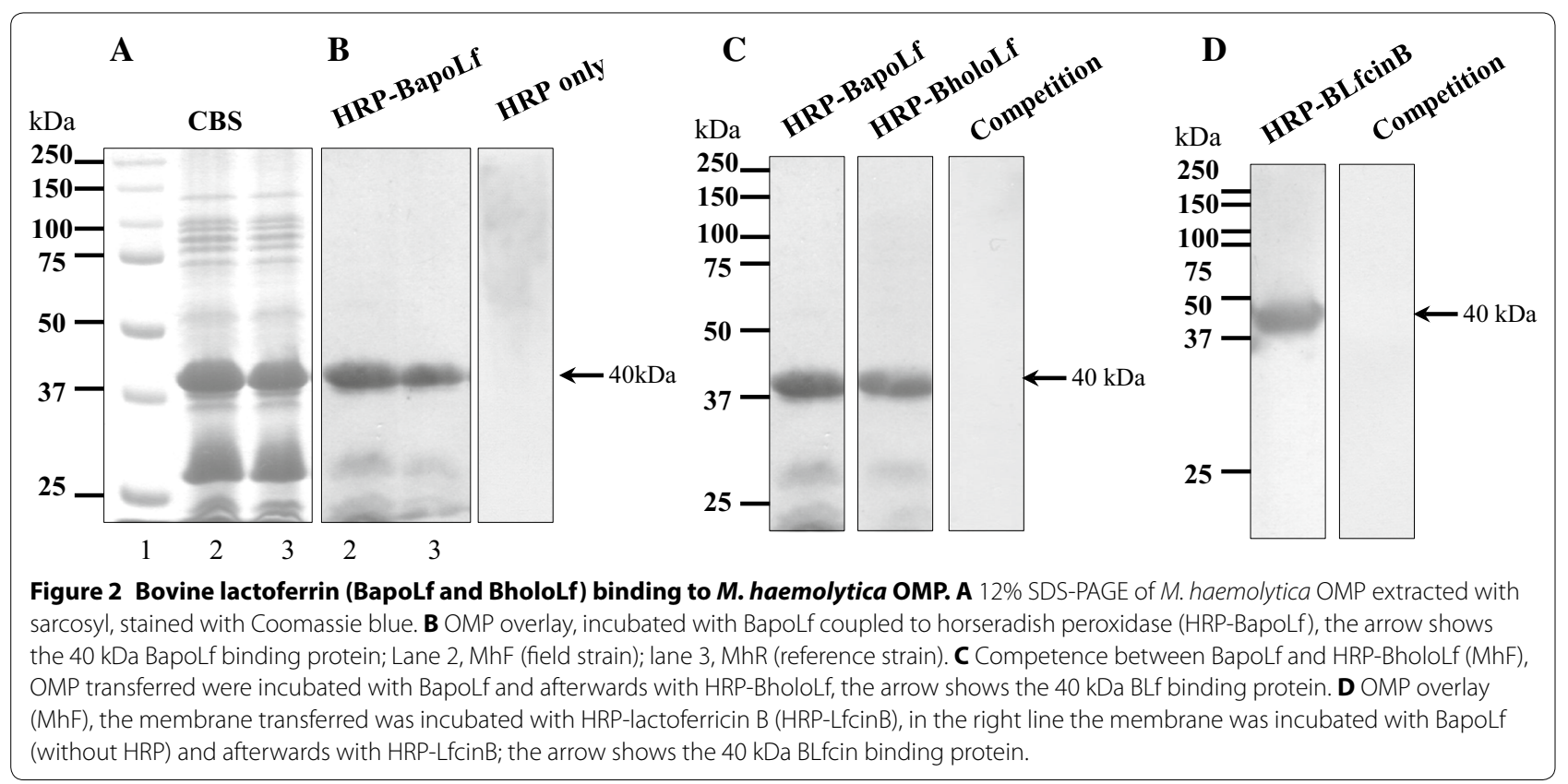

\section{Both MhHM and MhMP are transmembrane proteins}

MhHM and MhMP sequences were analyzed with MCMBB. The scores obtained were 0.028 for MhMH and 0.046 for MhMP; where a score greater than zero, indicates that the protein is more likely to be a $\beta$-barrel OMP. The analysis with Pred-TMBB confirmed the transmembrane localization of the proteins. Figure 5 shows how the amino acid sequence could be organized at the OM. 


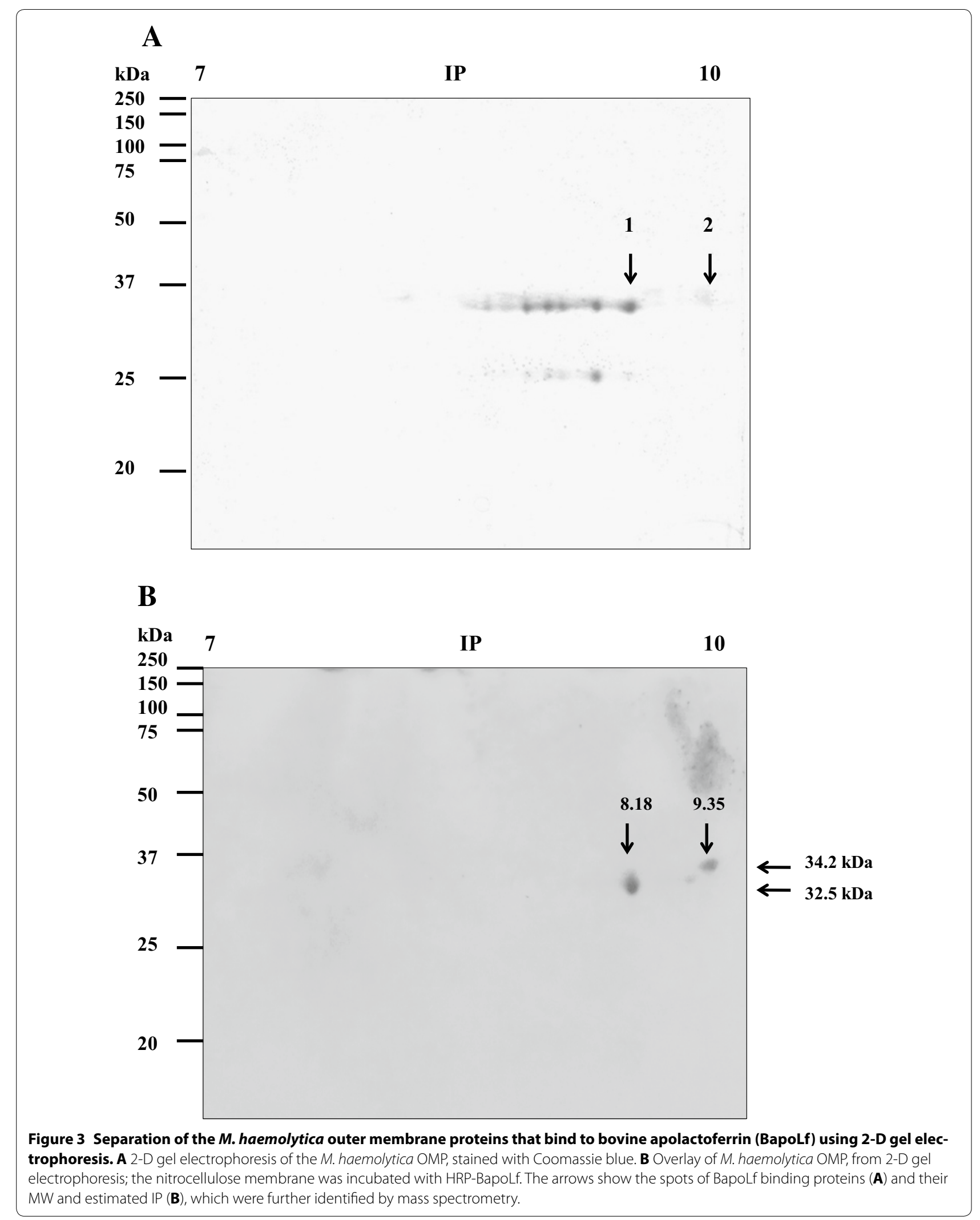


Table 1 Characteristics of the M. haemolytica outer membrane proteins identified by Maldi-Tof

\begin{tabular}{llllllll}
\hline Spot & Assigned names & $\begin{array}{l}\text { Accession } \\
\text { number }\end{array}$ & $\begin{array}{l}\text { Amino } \\
\text { acids }\end{array}$ & $\begin{array}{l}\text { Experimental } \\
\text { Mr(kDa)/IP }\end{array}$ & Gene & Signal peptide & Chain \\
\hline 1 & $\begin{array}{l}\text { Heat modifiable outer } \\
\text { membrane protein (MhHM) }\end{array}$ & $\begin{array}{l}\text { Q6XAY2 } \\
\text { gi|45758055 }\end{array}$ & 372 & $32.9 / 8.18$ & ompA & 1-19 position & 20-372 position \\
2 & Membrane protein (MhMP) & $\begin{array}{l}\text { S9YBF1 } \\
\text { gil544866807 }\end{array}$ & 353 & 34.2/9.35 & L278_12700 & 1-19 position & 20-353 position \\
\hline
\end{tabular}

Table 2 Identity of MhHM with related protein sequences (The data were obtained from the Blast program [38])

\begin{tabular}{llllc}
\hline Accession number & Protein & Max score & Query cover (\%) & Identity (\%) \\
\hline AA085792.1 & Heat-modifiable OMP (Mannheimia glucosida) & 666 & 100 & 95 \\
WP_005818116.1 & OMP P5 precursor (OMP P5) (Actinobacillus minor) & 556 & 95 & 82 \\
WP_025218170.1 & Membrane protein (Mannheimia varigena) & 555 & 100 & 83 \\
WP_040218887.1 & Membrane protein (Haemophilus parahaemolyticus) & 549 & 100 & 78 \\
WP_039198498.1 & Membrane protein (Actinobacillus equuli) & 540 & 100 & 75 \\
\hline
\end{tabular}

Table 3 Identity of MhMP with related protein sequences (The data were obtained from the Blast program [38])

\begin{tabular}{lllcc}
\hline Accession number & Protein & Max score & Query cover (\%) & Identity (\%) \\
\hline AGI35167.1 & OMP P2-like protein (Mannheimia haemolytica USDA-ARS-USMARC-185) & 638 & 100 & 91 \\
WP_025217393.1 & Membrane protein (Mannheimia varigena) & 506 & 100 & 91 \\
AHG75679.1 & OMP P2-like protein (Mannheimia varigena USDA-ARS-USMARC-1296) & 506 & 100 & 71 \\
WP_014991497.1 & Membrane protein (Actinobacillus suis) & 441 & 93 & 64 \\
WP_009874692.1 & Membrane protein (Actinobacillus pleuropneumoniae) & 427 & 100 & 61 \\
\hline
\end{tabular}

\section{Prediction of MhHM and MhMP 3-D model}

A predicted 3-D model for MhHM and MhMP was computed using the I-TASSER server. This analysis generated five top models; in the case of MhHM, the model number 3 was selected because it coincides with the structure of the MhHM protein domains, this model has a C-score of -3.56 (Figure 6A). C-score is typically in the range of -5 to 2 , where a $\mathrm{C}$-score of a higher value signifies a model with a higher confidence. A movie file shows in more detail the model of MhHM (Additional file 4). In the top ten threading templates used by I-Tasser, the OmpA of $E$. coli [PDB: 3nb3A] has the highest norm. Z-score (4.17), norm. Z-score is the normalized Z-score of the threading alignments; alignment with a normalized Z-score $>1$ means a good alignment and vice versa. Furthermore, the server COFACTOR of I-Tasser provides proteins with a highly similar structure; and often these proteins have similar function due to the structure similarity. For MhHM, the ranking 1 protein was the OmpA transmembrane domain of E. coli [PDB: 1BXW], with a TM-score of 0.404 (metric for measuring the structural similarity of two protein models) (Figure 6B). About the prediction of the ligand binding site, the OmpA-like domain from
Acinetobacter baumannii [PDB: 3TD4] was the ranking 1 protein, with a $\mathrm{C}$-score of 0.08 and consensus binding residues Glu236, Ala237, His272, Ala273, Ile275, Ser276, Leu280, Ala281, Ala284, Asn288, and His339; this OmpA-like domain has been crystallized and the binding to peptidoglycan has been reported (Figure 6C) [49].

For MhMP, the top ten threading templates used by I-Tasser included the OmpF of E. coli [PDB: $1 \mathrm{HXT}$ ] with Z-score of 4.0 and Omp32 of Delftia acidovorans [PDB: 2FGR] with a norm. Z-score of 4.35. The model of the 3-D structure for MhMP is shown in Figure 7A $(\mathrm{C}$-score $=1.02)$. An additional movie file shows the model of MhMP in more detail (Additional file 5). The Omp32 of $D$. acidovorans (TM-score $=0.914$ ), OmpC [PDB: 2XE1] (Figure 7B), and OmpF proteins of E. coli have the closest structural similarity to MhMP, with a TM-score of 0.847 and 0.843 , respectively. On the contrary, the prediction of the ligand binding site was the Delftia acidovorans Omp32; with a C-score of 0.03 and ligand binding sites residues Val10, Tyr11, Ala12, Phe13, Val53, Lys292, and Gly333. This Omp32 has calcium and sulfate ligands [BioLip: BL0089114] (Figure 7C) [50]. 


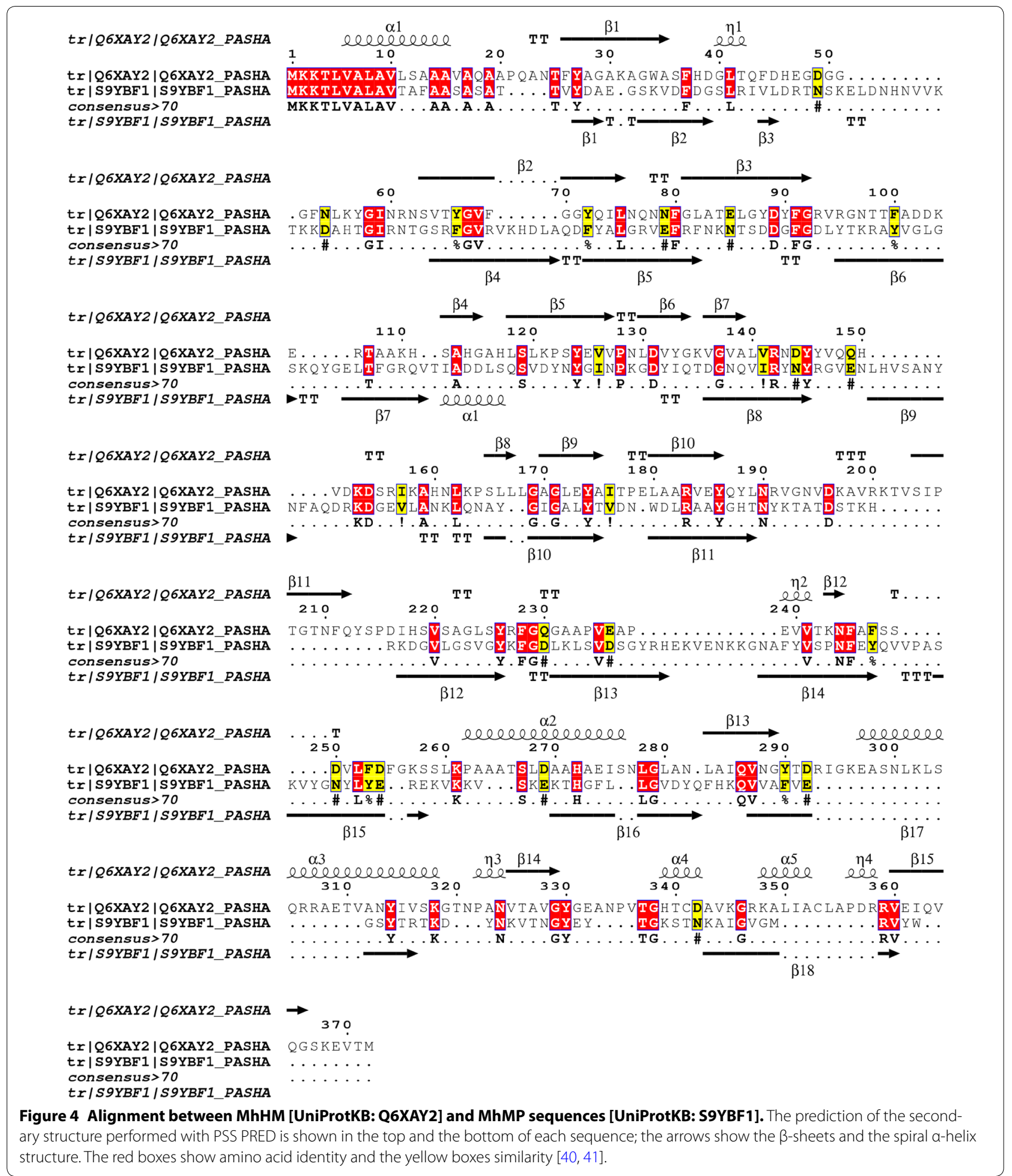

The quality estimation of 3-D models was calculated with QMEAN for both proteins (MhHM score $=0.415$ and MhMP score $=0.319$ ). For the two proteins, a sequence without signal peptide was considered to generate the 3-D model; this because it produces a better I-Tasser C-score and QMEAN score, although the 

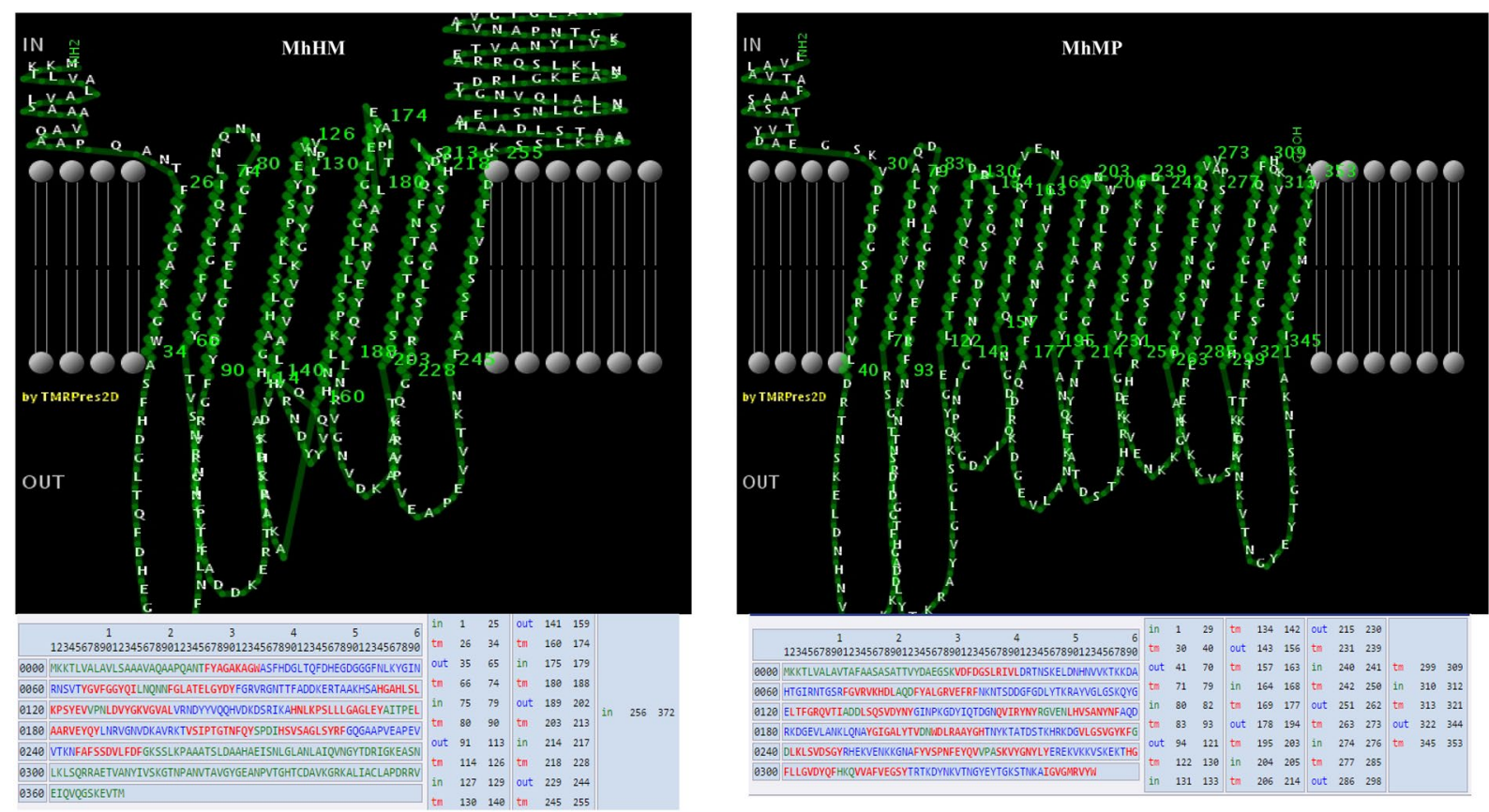

Figure 5 Prediction in Pred-TMBB of the protein localization at the membrane of MhHM and MhMP. In the sequence, amino acids in green represent the inner localization; amino acids in red, the transmembrane localization; amino acids in blue, the outside localization [44].

QMEAN score resulted low in both cases. This was expected because they have a $\beta$-barrel structure and are transmembrane proteins [51].

\section{Molecular docking between $M$. haemolytica MhHM and MhMP OMP and bovine lactoferrin}

The protein docking was predicted with the ClusPro server. The docking models between $M$. haemolytica OMP and BLf were chosen based on the predictions made in TMBB about the amino acids located outside of the bacterial membrane. Figure 8 shows the docking for MhHM and BholoLf [PDB: 1BLF] (BholoLf form is the only one available in the protein databank). The amino acids of MhHM involved in the docking are His38, Phe44, Asp49, Gly50, Gly51, Gly52, Asn54, Asp152, and Arg 191, corresponding to the outside predicted with Pred-TMBB and the BLf amino acids are Lys243, Glu659, Glu664, Thr688, and Arg689; the Lys243 residue is located in the $\mathrm{N}$-terminus and the other residues in C-terminus [52].

The docking between MhMP and BholoLf is represented in Figure 9. In this case, the residues involved are Phe93, Lys95, Ser98, Asp99, Asp100, and Asp104 of the MhMP, and Gln13, Arg38, Glu176, Gly177, Asn179, and Arg186 for BholoLf corresponding to the N-terminus, responsible for the bactericidal effect. Additional movie files show in more detail the docking between the proteins (Additional files 6 and 7).

\section{Discussion}

Our results point out that $M$. haemolytica is not able to use BholoLf as a sole iron source for growth. Ogunnariwo and Schryvers [18] looked for the $l b p A$ and $l b p B$ sequences in several members of the Pasteurellaceae family by PCR; these genes encode for proteins LbpA and LbpB, which are OMP that allow Neisseriaceae family bacteria to take up the iron from holoLf. As they found no amplification of these sequences in M. haemolytica, our results complement those from these authors; however, we cannot discard the binding of $M$. haemolytica to BholoLf through an alternative mechanism to the known Lbps.

BapoLf showed a bactericidal effect for $M$. haemolytica. In other members of the Pasteurellaceae family, the bactericidal effect of apoLf has also been described; our group reported a higher MIC $(11.78 \mu \mathrm{M})$ for BapoLf in the pig pathogen A. pleuropneumoniae serotype 1, than the MIC $(4.88 \pm 1.88$ and $7.31 \pm 1.62 \mu \mathrm{M})$ obtained in $M$. haemolytica in this work [28]. In other studies, a lower concentration of HapoLf $(3.8 \mu \mathrm{M})$ was found for killing the human oral pathogen A. actinomycetemcomitans [53]. Therefore, the MIC we obtained for BapoLf in M. haemolytica are within the range of those for other species [54]. As BapoLf was bactericidal in vitro for M. haemolytica, it also could have a similar effect in this species in vivo and could be used against bovine Mannheimiosis. The 


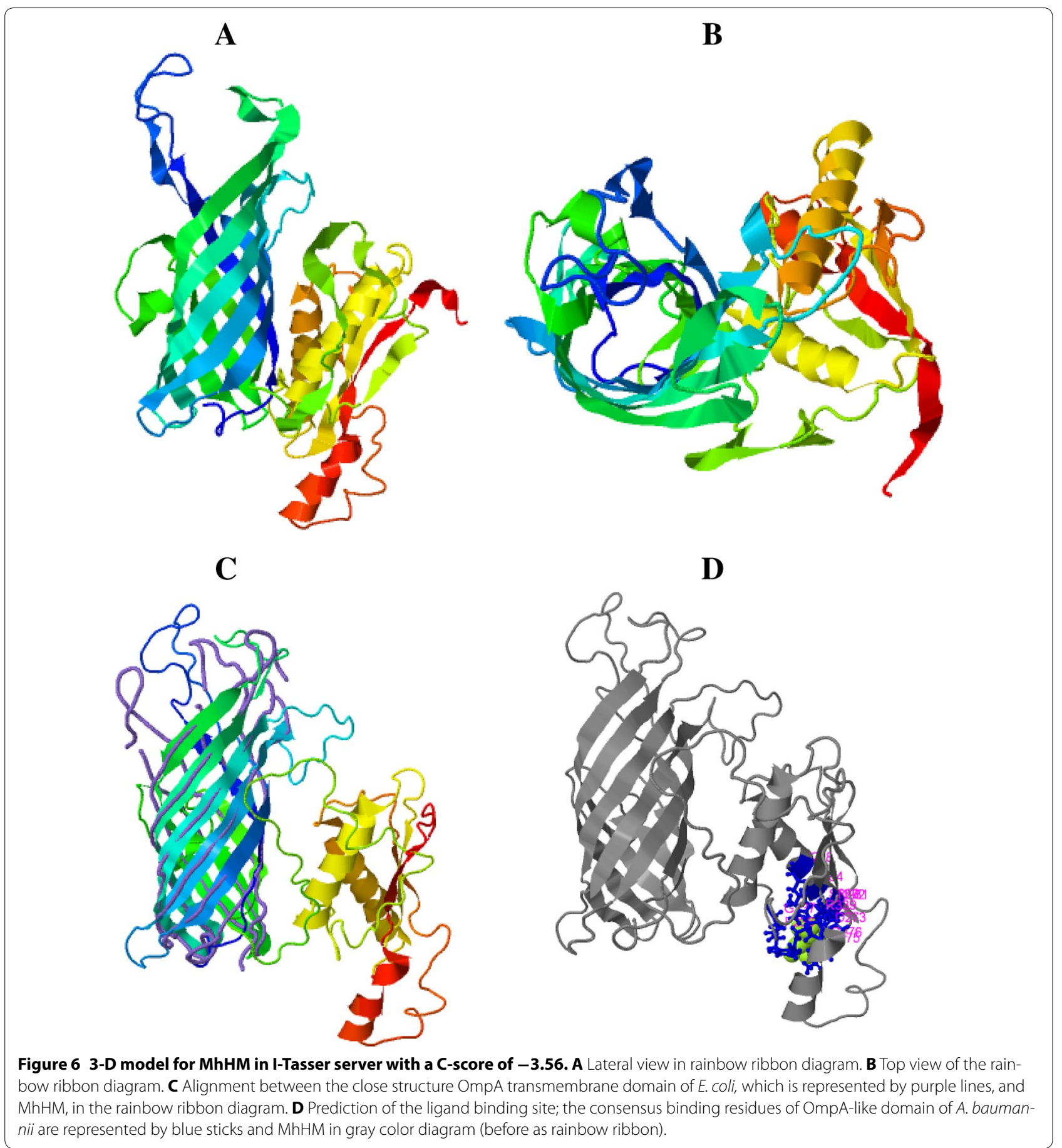

bactericidal effect of BLf could be due to the binding of cationic BapoLf to the anionic M. haemolytica surface, and/or to the interaction with MhHM and MhMP proteins, in both cases leading to an OM destabilization, as occurs in other bacteria [24].

The IEF assay shows that $M$. haemolytica possesses two BLf binding proteins, one of $32.9 \mathrm{kDa}$ and another one of $34.2 \mathrm{kDa}$ with estimated IP of 8.18 and 9.35, respectively. The MW were different from that observed in 1-D (40 kDa), perhaps due to the boiling sample preparation in 1-D and the heat-modifiable property of the OmpA (see below) [55]. By Maldi TOF/TOF 4800 analysis, the proteins corresponded to the heat modifiable OMP (MhHM) and an unknown OMP (MhMP) of 


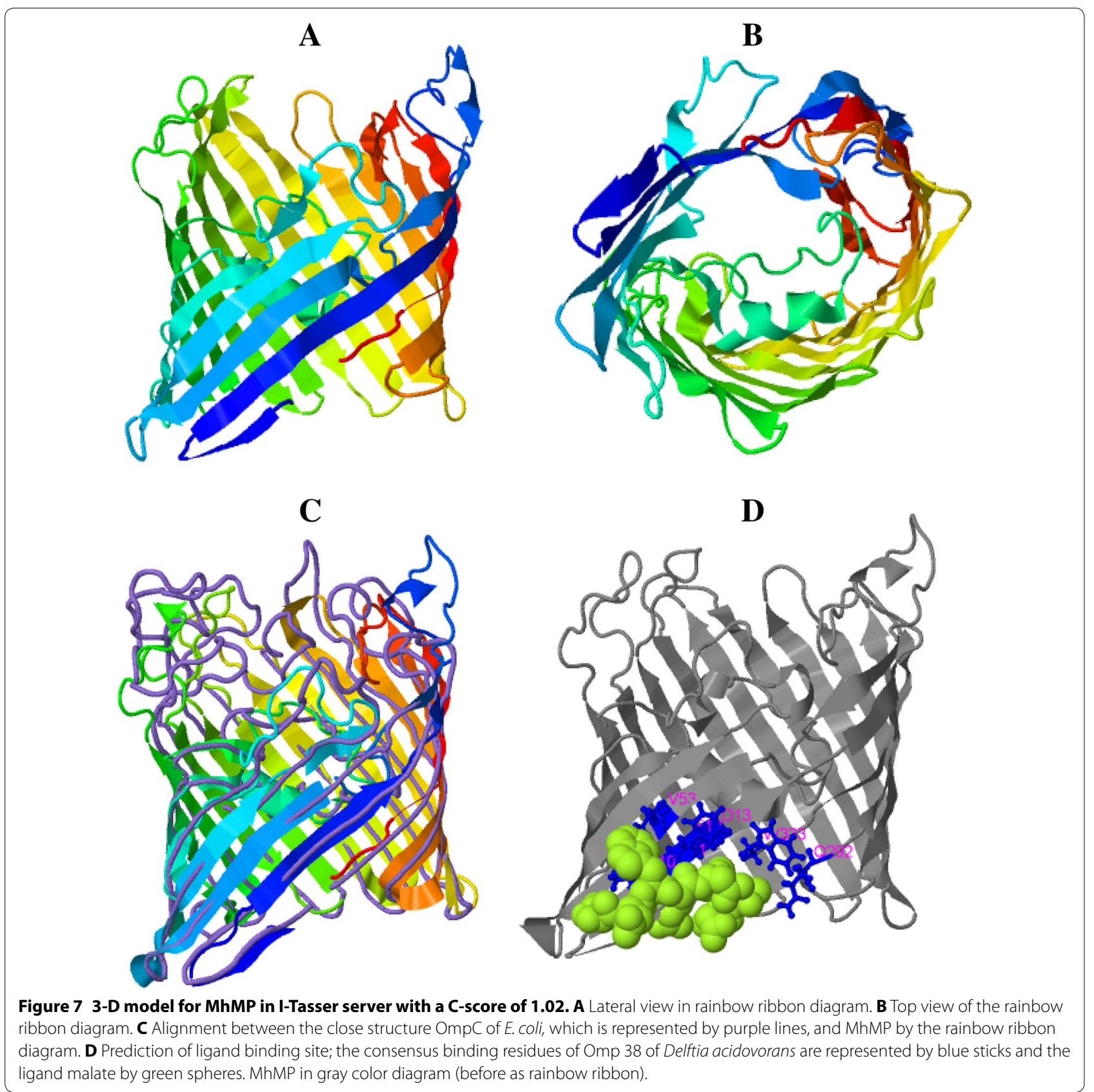

M. haemolytica, respectively. MhHM is encoded by the ompA gene, whereas L278_12700 gene encodes MhMP. Sequences of MhHM and MhMP were aligned with Clustal Omega, a multiple sequence alignment program that uses seeded guide trees and HMM profile-profile techniques to generate alignments between sequences. The differences in the sequences demonstrate that they are two different proteins of $M$. haemolytica; nevertheless, the identity regions could be the BLf binding sites in both OMP. Apparently, the site of BLf interaction with
M. haemolytica OMP is the N-terminus, since BLfcin (BLf 4-14 peptide) avoids the binding with BapoLf in the competition binding assays; and HRP-BLfcin also binds to the $40 \mathrm{kDa}$ band. Our results showing that the same OMP can bind BapoLf and BholoLf, agree with those for HapoLf and HholoLf binding to OmpC and OmpF in enteropathogenic Escherichia coli (EPEC) [26]. As BapoLf and BholoLf are bound to the same M. haemolytica OMP, thus the function of these Lf binding proteins in vivo could be explained in two ways: BapoLf binding 


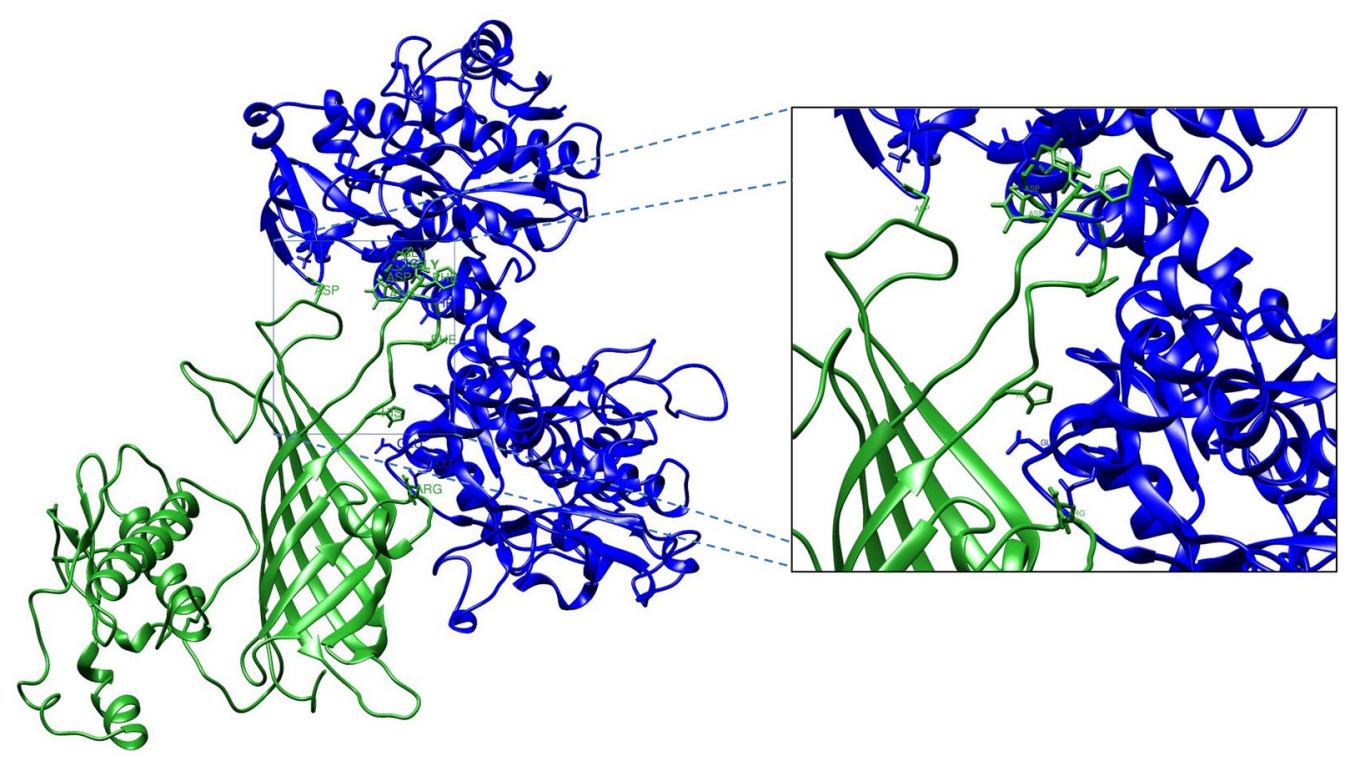

Figure 8 Molecular docking between MhHM model (green ribbon diagram) and bovine lactoferrin (blue ribbon diagram). The residues in sticks representation show the possible amino acids involved in the docking between the two proteins [47].

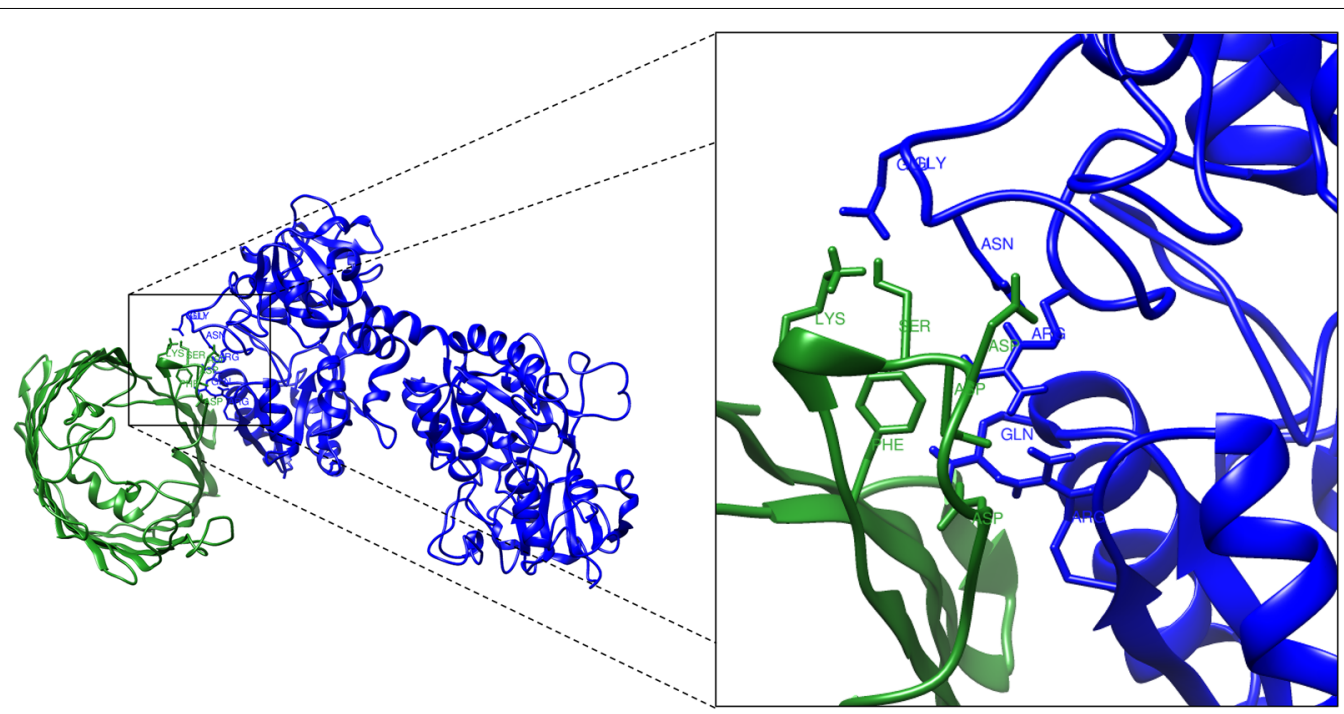

Figure 9 Molecular docking between MhMP model (green ribbon diagram) and bovine lactoferrin (blue ribbon diagram). The residues in sticks representation show the possible amino acids involved in the docking between the two proteins [47].

to $M$. haemolytica OMP causes bacterial death and then the binding might help to avoid the infection process. As $M$. haemolytica Lf binding proteins cannot discriminate between the iron content of BLf, thus the binding site to BLf could not be related with iron binding. On the contrary, we found that $M$. haemolytica did not use BholoLf as an iron source, thus we can speculate that this ironcharged protein could be participating in the inhibition of some pathogenicity mechanisms in this bacterial species, such as occurs in the biofilm production by $A$. pleuropneumoniae [28]. In this context, BholoLf reduced the adhesion of enterotoxigenic E. coli (ETEC) to the JTC17 cell line and different portions of mouse intestine [56]. In addition, [57] reported that BholoLf (30\% iron saturation) suppressed the adhesion of EPEC to HEp-2 cells by $88 \%$. Other experiments are necessary to demonstrate the role that MhHM (OmpA) and MhMP (porin) play in M. haemolytica in their interaction with BholoLf. 
Protein domains were searched in the website InterPro, which is a resource that provides functional analysis of protein sequences by classifying them into families and predicting the presence of domains and important sites. MhHM possesses two domains, OmpA-like and OmpA$\mathrm{C}$ like. Well-studied OmpA domains containing proteins in bacteria include OmpA, lipoprotein PAL, motor protein MotB in E. coli, RmpM of Neisseria meningitidis that interacts with other components of the OM, and the Vibrio alginolyticus flagellar motor proteins PomB and MotY that interact with the inner membrane [58]. The OmpA protein is an integral component of the OM and is highly conserved in Gram negative bacteria. The protein has characteristic heat-modifiable properties [59], is present in a high copy number $\left(>10^{5} /\right.$ cell $)$, and is immunogenic [60]. Functions that have been attributed to OmpA include the maintenance of OM integrity and cell shape. OmpA also has other roles, for example, it acts as a bacteriophage receptor, takes part in conjugation, and confers resistance to the bactericidal effect of the serum [61]. In $M$. haemolytica the ompA gene has been cloned and sequenced and the immunological properties of OmpA have been investigated [11]. In addition, OmpA fibronectin-binding activity has been demonstrated [62], as well as the binding to bovine bronchial epithelial cells [12]. Therefore, the binding of BapoLf to MhHM (OmpA) could alter the OM integrity and cause bacterial death; additionally it may affect binding to fibronectin and epithelial cells, which possibly decreases bacterial adherence. In accordance with that, in other pathogens like $E$. coli and Shigella dysenteriae, the inhibition caused by Lf in bacterial adherence has been reported [63, 64].

Concerning MhMP, this OMP possesses the conserved Gram-negative porin domain; the porins form ion selective channels for small hydrophilic molecules. $\mathrm{X}$-ray structured analyses of several bacterial porins have revealed a large 16 stranded anti-parallel structure enclosing the transmembrane pore. Trimers are stabilized by hydrophilic clamping of loop L2 [65]. Currently, the function of MhMP is unknown.

MhHM and MhMP sequences were analyzed with $\mathrm{MCMBB}$, an algorithm that achieves high accuracy in discriminating $\beta$-barrel OMP from globular and alphahelical membrane proteins. The model allows a correct classification rate of $90.08 \%$ for $\beta$-barrel proteins and of 92.67\% for globular proteins. When submitting alphahelical membrane proteins to analysis, the method shows $100 \%$ accuracy. Also, the analysis with Pred-TMBB, a method based on a Hidden Markov Model, capable of predicting the transmembrane beta-strands of the Gramnegative bacteria OMP, and of discriminating such proteins from water-soluble ones when screening large datasets, confirms the transmembrane localization of the proteins, and how the amino acid sequences could been organized at the OM. These in silico analyses strongly suggest that the structures of MhHM and MhMP are $\beta$-barrel and transmembrane proteins.

By using the I-TASSER server, MhHM protein possesses a similar structure to the OmpA transmembrane domain of $E$. coli. The ligand binding site was similar to the OmpA-like domain from Acinetobacter baumannii; this OmpA-like domain has been crystallized and the binding to peptidoglycan has been reported [49]. MhMP has a porin structure, and a correlation between Lf binding to porins and the Lf-mediated antimicrobial bactericidal effect has been reported in other bacterial species [66]. Erdei et al. [26] presented evidence for Lf interaction with porins OmpF and OmpC. These porins bind to HapoLf and HholoLf in E. coli which seems to be accountable for the antimicrobial effect of Lf in $E$. coli; these data fully agree with the results found in the present work, since BapoLf has a bactericidal effect in $M$. haemolytica and binds to the putative porin MhMP, structurally close to OmpF and OmpC.

The protein docking was predicted with the ClusPro server. The docking algorithms evaluate billions of putative complexes, retaining a preset number with favorable surface complementarities. A filtering method is then applied to this set of structures, selecting those with good electrostatic and desolvation free energies for further clustering. The program output is a short list of putative complexes ranked according to their clustering properties [67]. The docking residues of MhMP are localized in loop 2 , which is the site of interaction to form the homotrimer. Possibly, the BLf binding could affect the homotrimer conformation and in consequence produce a membrane destabilization. Interestingly, the BLf is predicted to bind to different sites at the $M$. haemolytica Omps, the C-terminus within MhHM and the N-terminus within MhMP, and in different residues of the Omps. Because the models are approximations of how the proteins could be binding, and since other components found in the OM are not considered, this study provides only a guide of the possible binding sites and further studies are needed to confirm these results.

In conclusion, this work sheds light on the relationship between $M$. haemolytica and BLf: it was determined that $M$. haemolytica does not use BholoLf as a sole iron source, and that BapoLf displays a bactericidal effect on M. haemolytica. Both forms of the protein bind to proteins MhHM and MhMP. This interaction could be responsible for the bactericidal effect of BapoLf on $M$. haemolytica, in agreement to what happens in other Gram negative bacteria. The results suggest that BapoLf could be added to the bovine mannheimiosis treatment to help eliminate the infection process in vivo. 


\section{Additional files}

Additional file 1. Mannheimia haemolytica growth in different concentrations of the chelating agent $\mathbf{2}$ ' $\mathbf{2}$ dipyridyl. $M$. haemolytica strain $\mathrm{F}$ (field isolate) and strain $\mathrm{R}$ (reference strain) were grown in $\mathrm{BHI}$ broth with 2,2'-dipyridyl, and OD (595 nm) was recorded at 0 and $18 \mathrm{~h}$ of incubation at $37^{\circ} \mathrm{C}$ in agitation (200 rpm).

Additional file 2. List of peptides obtained by Maldi-Tof/Tof to identify the spot 1. MhHM score 125 , Protein score is $-10^{*} \log (P)$, where $P$ is the probability that the observed match is a random event. Protein scores greater than 86 are significant $(p<0.05)$. Protein scores greater than 86 are significant $(p<0.05)$. Protein sequence coverage $34 \%$.

Additional file 3. List of peptides obtained by Maldi-Tof/Tof to identify the spot 2. MhMP score 124, Protein score is $-10^{*} \log (P)$, where $P$ is the probability that the observed match is a random event. Protein scores greater than 86 are significant $(p<0.05)$. Protein scores greater than 86 are significant $(p<0.05)$. Protein sequence coverage $39 \%$.

Additional file 4. Video of the MhHM protein 3-D model. This video shows the 3-D structure of MhHM obtained by I-Tasser server (cartoon representation). Domain OmpA and domain OmpA-C like are observed in blue-green and yellow-orange colors, respectively.

Additional file 5. Video of the MhMP protein 3-D model. This video shows the 3-D structure of MhMP obtained by by I-Tasser server and visualized with Chimera (cartoon representation). Porin domain is observed in rainbow colors.

Additional file 6. Video of the molecular docking between MhHM and BLf. This video shows the docking obtained by ClusPro server and visualized with Chimera (cartoon representation). MhHM is observed in green and bovine lactoferrin in blue. The residues in sticks representation show the possible binding between the two proteins.

Additional file 7. Video of the molecular docking between MhMP and BLf. This video shows the docking obtained by ClusPro server and visualized with Chimera (cartoon representation). MhMP is observed in green and bovine lactoferrin in blue. The residues in sticks representation show the possible binding between the two proteins.

\section{Abbreviations}

HapoLf: human apolactoferrin; HholoLf: human hololactoferrin; Lf: lactoferrin; BapoLf: bovine apolactoferrin; BholoLf: bovine hololactoferrin; OMP: outer membrane proteins; MIC: minimal inhibitory concentration; MhF: M. haemolytica field strain; MhR: M. haemolytica reference strain; OM: outer membrane; BLfcin: bovine lactoferricin; IP: isoelectric point; IPG: immobilized pH gradient IEF: isoelectrofocusing; EPEC: enteropathogenic E. coli; ETEC: enterotoxigenic E. coli.

\section{Competing interests}

The authors declare that they have no competing interests.

\section{Authors' contributions}

LSB carried out the experimental work, participated in the study design and prepared the manuscript. CPV and SLC participated in acquisition, analysis and interpretation of data. FSG participated in the design and helped draft the manuscript. MGA conceived the study and participated in its design and coordination and helped draft the manuscript. All authors read and approved the final manuscript.

\section{Acknowledgements}

First author received a doctorate scholarship from CONACyT, Mexico, No. 70444 and from COMECyT, Mexico, No. 15BEPD0005-II. We thank Dr. Juan Pedro Luna Arias for his advice in bioinformatic tools.

\section{Author details}

${ }^{1}$ Departamento de Biología Celular, Centro de Investigación y de Estudios Avanzados del IPN (CINVESTAV-IPN), Avenida Instituto Politécnico Nacional No. 2508, Colonia San Pedro Zacatenco, CP 07360 Ciudad de México, Mexico.
${ }^{2}$ Facultad de Medicina Veterinaria y Zootecnia Dr. Norberto Treviño Zapata, Universidad Autónoma de Tamaulipas, Carretera a Cd. Mante Km 5, CP 87000 Ciudad Victoria, Tamaulipas, Mexico. ${ }^{3}$ Departamento de Microbiología, Facultad de Medicina Veterinaria y Zootecnia, Universidad Nacional Autónoma de México (UNAM), Av. Universidad 3000, Cd. Universitaria, Coyoacán, CP 04510 Ciudad de México, Mexico.

Received: 24 February 2016 Accepted: 14 July 2016

Published online: 06 September 2016

\section{References}

1. Zecchinon L, Fett T, Desmecht D (2005) How Mannheimia haemolytica defeats host defence through a kiss of death mechanism. Vet Res 36:133-156

2. Kirchhoff J, Uhlenbruck S, Goris K, Keil GM, Herrler G (2014) Three viruses of the bovine respiratory disease complex apply different strategies to initiate infection. Vet Res 45:20

3. Mosier D (2014) Review of BRD pathogenesis: the old and the new. Anim Health Res Rev 15:166-168

4. Taylor JD, Fulton RW, Lehenbauer TW, Step DL, Confer AW (2010) The epidemiology of bovine respiratory disease: what is the evidence for predisposing factors? Can Vet J 51:1095-1102

5. Jaramillo-Arango C, Hernandez-Castro R, Suarez-Guemes F, MartinezMaya J, Aguilar-Romero F, Jaramillo-Meza L, Trigo F (2008) Characterisation of Mannheimia spp. strains isolated from bovine nasal exudate and factors associated to isolates, in dairy farms in the Central Valley of Mexico. Res Vet Sci 84:7-13

6. Chang YF, Young R, Post D, Struck DK (1987) Identification and characterization of the Pasteurella haemolytica leukotoxin. Infect Immun 55:2348-2354

7. Li J, Clinkenbeard KD (1999) Lipopolysaccharide complexes with Pasteurella haemolytica leukotoxin. Infect Immun 67:2920-2927

8. Adlam C, Knights J, Mugridge A, Lindon J, Baker P, Beesley J, Spacey B, Craig G, Nagy L (1984) Purification, characterization and immunological properties of the serotype-specific capsular polysaccharide of Pasteurella haemolytica (serotype A1) organisms. J Gen Microbiol 130:2415-2426

9. Davies RL, McCluskey J, Gibbs HA, Coote JG, Freer JH, Parton R (1994) Comparison of outer-membrane proteins of Pasteurella haemolytica expressed in vitro and in vivo in cattle. Microbiology 140:3293-3300

10. Pandher K, Confer AW, Murphy GL (1998) Genetic and immunologic analyses of PIpE, a lipoprotein important in complement-mediated killing of Pasteurella haemolytica serotype 1. Infect Immun 66:5613-5619

11. Zeng H, Pandher K, Murphy GL (1999) Molecular cloning of the Pasteurella haemolytica pomA gene and identification of bovine antibodies against PomA surface domains. Infect Immun 67:4968-4973

12. Kisiela DI, Czuprynski CJ (2009) Identification of Mannheimia haemolytica adhesins involved in binding to bovine bronchial epithelial cells. Infect Immun 77:446-455

13. Potter AA, Ready K, Gilchrist J (1988) Purification of fimbriae from Pasteurella haemolytica A1. Microb Pathog 4:311-316

14. Abdullah K, Lo R, Mellors A (1991) Cloning, nucleotide sequence, and expression of the Pasteurella haemolytica A1 glycoprotease gene. J Bacteriol 173:5597-5603

15. Chang YF, Ma DP, Bai HQ, Young R, Struck DK, Shin SJ, Lein DH (1992) Characterization of plasmids with antimicrobial resistant genes in Pasteurella haemolytica A1. DNA Seq 3:89-97

16. Kehrenberg C, Salmon SA, Watts JL, Schwarz S (2001) Tetracycline resistance genes in isolates of Pasteurella multocida, Mannheimia haemolytica, Mannheimia glucosida and Mannheimia varigena from bovine and swine respiratory disease: intergeneric spread of the tet $(\mathrm{H})$ plasmid pMHT1. J Antimicrob Chemother 48:631-640

17. Kehrenberg C, Schwarz S (2001) Occurrence and linkage of genes coding for resistance to sulfonamides, streptomycin and chloramphenicol in bacteria of the genera Pasteurella and Mannheimia. FEMS Microbiol Lett 205:283-290

18. Ogunnariwo JA, Schryvers AB (1990) Iron acquisition in Pasteurella haemolytica: expression and identification of a bovine-specific transferrin receptor. Infect Immun 58:2091-2097 
19. Roehrig SC, Tran HQ, Spehr V, Gunkel N, Selzer PM, Ullrich HJ (2007) The response of Mannheimia haemolytica to iron limitation: implications for the acquisition of iron in the bovine lung. Vet Microbiol 121:316-329

20. Baker HM, Baker EN (2004) Lactoferrin and iron: structural and dynamic aspects of binding and release. Biometals 17:209-216

21. Vogel HJ (2012) Lactoferrin, a bird's eye view. Biochem Cell Biol 90:233-244

22. Farnaud S, Evans RW (2003) Lactoferrin - a multifunctional protein with antimicrobial properties. Mol Immunol 40:395-405

23. Appelmelk BJ, An YQ, Geerts M, Thijs BG, de Boer HA, MacLaren DM, de Graaff J, Nuijens JH (1994) Lactoferrin is a lipid A-binding protein. Infect Immun 62:2628-2632

24. Drago-Serrano M (2006) Antibacterial activities of lactoferrin. Enf Inf Microbiol 26:58-63

25. Ellison RT 3rd, Giehl TJ, LaForce FM (1988) Damage of the outer membrane of enteric gram-negative bacteria by lactoferrin and transferrin. Infect Immun 56:2774-2781

26. Erdei J, Forsgren A, Naidu AS (1994) Lactoferrin binds to porins OmpF and OmpC in Escherichia coli. Infect Immun 62:1236-1240

27. Orsi N (2004) The antimicrobial activity of lactoferrin: current status and perspectives. Biometals 17:189-196

28. Luna-Castro S, Aguilar-Romero F, Samaniego-Barron L, Godinez-Vargas D, de la Garza M (2014) Effect of bovine apo-lactoferrin on the growth and virulence of Actinobacillus pleuropneumoniae. Biometals 27:891-903

29. Velusamy SK, Ganeshnarayan K, Markowitz K, Schreiner H, Furgang D, Fine DH, Velliyagounder K (2013) Lactoferrin knockout mice demonstrates greater susceptibility to Aggregatibacter actinomycetemcomitans-induced periodontal disease. J Periodontol 84:1690-1701

30. Ling JM, Schryvers AB (2006) Perspectives on interactions between lactoferrin and bacteria. Biochem Cell Biol 84:275-281

31. Schryvers $A B$ (1989) Identification of the transferrin- and lactoferrinbinding proteins in Haemophilus influenzae. J Med Microbiol 29:121-130

32. Yu RH, Schryvers AB (2002) Bacterial lactoferrin receptors: insights from characterizing the Moraxella bovis receptors. Biochem Cell Biol 80:81-90

33. Schryvers AB, Morris $L J$ (1988) Identification and characterization of the human lactoferrin-binding protein from Neisseria meningitidis. Infect Immun 56:1144-1149

34. Brennan R, Corstvet R, McBride J (1997) A simplified method for isolating outer membrane proteins from Pasteurella haemolytica A1. J Microbiol Methods 29:201-206

35. Bradford MM (1976) A rapid and sensitive method for the quantitation of microgram quantities of protein utilizing the principle of protein-dye binding. Anal Biochem 72:248-254

36. Image processing and analysis in Java. http://imagej.nih.gov/ij/. Accessed 22 Feb 2015

37. Matrix Science. http://www.matrixscience.com/. Accessed 15 May 2015

38. Basic Local Alignment Search Tool. http://blast.ncbi.nlm.nih.gov/. Accessed 5 Sep 2015

39. Institute TEB. Clustal omega. http://www.ebi.ac.uk/Tools/msa/clustalo/. Accessed 10 Oct 2015

40. Michigan Uo, Group YZsR. Protein secondary structure prediction (PSSpred). http://zhanglab.ccmb.med.umich.edu/PSSpred/. Accessed 5 Dec 2015

41. ESPRIPT 3.0. http://espript.ibcp.fr/ESPript/cgi-bin/ESPript.cgi. Accessed 5 Dec 2015

42. Institute TEB. InterPro: protein sequence analysis and classification. http:// www.ebi.ac.uk/interpro/. Accessed 8 Dec 2015

43. MCMBB: Markov chain model for beta barrels. http://athina.biol.uoa.gr/ bioinformatics/mcmbb/. Accessed 8 Nov 2015

44. Pred-TMBB A Hidden Markov Model method, capable of predicting and discriminating beta-barrel outer membrane proteins. http://biophysics. biol.uoa.gr/PRED-TMBB/. Accessed 10 Nov 2015

45. Michigan Uo, Group YZsR. I-Tasser: protein structure and prediction. http://zhanglab.ccmb.med.umich.edu/l-TASSER/. Accessed 10 Dec 2015

46. Bioinformatics Slo. QMEAN server for model quality estimation. http:// swissmodel.expasy.org/qmean/cgi/index.cgi. Accessed 28 Jan 2016

47. ClusPro: protein-protein docking. http://cluspro.bu.edu/home.php. Accessed 7 Jan 2016
48. Resource for Biocomputing $\vee$, and Informatics at the University of California, San Francisco. USCF Chimera: an extensible molecular modeling system. http://www.cgl.ucsf.edu/chimera. Accessed 10 Jan 2016

49. Park JS, Lee WC, Song JH, Kim SI, Lee JC, Cheong C, Kim HY (2012) Purification, crystallization and preliminary $\mathrm{X}$-ray crystallographic analysis of diaminopimelate epimerase from Acinetobacter baumannii. Acta Crystallogr Sect F Struct Biol Cryst Commun 69:42-44

50. Zachariae U, Kluhspies T, De S, Engelhardt H, Zeth K (2006) High resolution crystal structures and molecular dynamics studies reveal substrate binding in the porin Omp32. J Biol Chem 281:7413-7420

51. Benkert P, Tosatto SC, Schomburg D (2008) QMEAN: a comprehensive scoring function for model quality assessment. Proteins 71:261-277

52. Gonzalez-Chavez SA, Arevalo-Gallegos S, Rascon-Cruz Q (2009) Lactoferrin: structure, function and applications. Int J Antimicrob Agents 33:301-308

53. Kalmar J, Arnold R (1988) Killing of Actinobacillus actinomycetemcomitans by human lactoferrin. Infect Immun 56:2552-2557

54. Bellamy W, Takase M, Yamauchi K, Wakabayashi H, Kawase K, Tomita M (1992) Identification of the bactericidal domain of lactoferrin. Biochim Biophys Acta 1121:130-136

55. Davies RL, Lee I (2004) Sequence diversity and molecular evolution of the heat-modifiable outer membrane protein gene (ompA) of Mannheimia (Pasteurella) haemolytica, Mannheimia glucosida, and Pasteurella trehalosi. J Bacteriol 186:5741-5752

56. Kawasaki Y, Tazume S, Shimizu K, Matsuzawa H, Dosako S, Isoda H, Tsukiji M, Fujimura R, Muranaka Y, Isihida H (2000) Inhibitory effects of bovine lactoferrin on the adherence of enterotoxigenic Escherichia coli to host cells. Biosci Biotechnol Biochem 64:348-354

57. Flores-Villasenor H, Canizalez-Roman A, de la Garza M, Nazmi K, Bolscher $J G$, Leon-Sicairos N (2012) Lactoferrin and lactoferrin chimera inhibit damage caused by enteropathogenic Escherichia coli in HEp-2 cells. Biochimie 94:1935-1942

58. Yorimitsu T, Sato K, Asai Y, Kawagishi I, Homma M (1999) Functional interaction between PomA and PomB, the $\mathrm{Na}(+)$-driven flagellar motor components of Vibrio alginolyticus. J Bacteriol 181:5103-5106

59. Beher MG, Schnaitman CA, Pugsley AP (1980) Major heat-modifiable outer membrane protein in gram-negative bacteria: comparison with the ompA protein of Escherichia coli. J Bacteriol 143:906-913

60. Mahasreshti PJ, Murphy GL, Wyckoff JH 3rd, Farmer S, Hancock RE, Confer AW (1997) Purification and partial characterization of the OmpA family of proteins of Pasteurella haemolytica. Infect Immun 65:211-218

61. Weiser JN, Gotschlich EC (1991) Outer membrane protein A (OmpA) contributes to serum resistance and pathogenicity of Escherichia coli K-1. Infect Immun 59:2252-2258

62. Lo RY, Sorensen LS (2007) The outer membrane protein OmpA of Mannheimia haemolytica $\mathrm{A} 1$ is involved in the binding of fibronectin. FEMS Microbiol Lett 274:226-231

63. Nascimento de Araujo A, Giugliano LG (2000) Human milk fractions inhibit the adherence of diffusely adherent Escherichia coli (DAEC) and enteroaggregative E. coli (EAEC) to HeLa cells. FEMS Microbiol Lett 184:91-94

64. Willer Eda M, Lima Rde L, Giugliano LG (2004) In vitro adhesion and invasion inhibition of Shigella dysenteriae, Shigella flexneri and Shigella sonnei clinical strains by human milk proteins. BMC Microbiol 4:18

65. Dhakshnamoorthy B, Raychaudhury S, Blachowicz L, Roux B (2010) Cation-selective pathway of OmpF porin revealed by anomalous X-ray diffraction. J Mol Biol 396:293-300

66. Naidu SS, Svensson U, Kishore AR, Naidu AS (1993) Relationship between antibacterial activity and porin binding of lactoferrin in Escherichia coli and Salmonella typhimurium. Antimicrob Agents Chemother 37:240-245

67. Comeau SR, Gatchell DW, Vajda S, Camacho CJ (2004) ClusPro: a fully automated algorithm for protein-protein docking. Nucleic Acids Res 32:W96-99 